\title{
IMPROVING ENGLISH WRITING SKILL OF ELEMENTARY STUDENTS BY USING WHAT'S MISSING METHODS
}

\author{
Ade Christianti $^{1}$, Dayu Retno Puspita ${ }^{2}$, Ahmad Arif Fadillah ${ }^{3}$ \\ Muhammadiyah Tangerang University, Indonesia \\ ade_christianti@yahoo.com ${ }^{1}$ retno_dayu@yahoo.com²
}

\begin{abstract}
This study aims to determine the effect of students' writing skills on English subjects using the 'What Missing' method. This study used a quasi-experimental research method with the research design of Nonequivalent Control Group Design. The population subjects in this study were 76th grade students of Kampung Melayu 1 Elementary School 1 Tangerang Regency. Data collection techniques using question instruments test essay writing skills To test the pretest hypothesis in this study used the test, from the results of the $\mathrm{t}$ test obtained $\mathrm{t}$ count $=-0.3<\mathrm{t}$ table $=2.00$. Whereas for testing the posttest hypothesis from the results of the $t$ test it is obtained $t$ count $=6.06>t$ table $=2.00$, it can be concluded that there is a significant effect between the posttest value of the control class and the experimental class. This can be interpreted that the use of the What's Missing method is very influential on students' English writing skills.
\end{abstract}

Keywords: What's Missing method, English writing skill

CPendidikan Bahasa Inggris FPISH IKIP BU Malang

\section{INTRODUCTION}

Learning languages in everyday life plays an important role especially in the disclosure of one's thoughts or is a means to think, reason and live life. In everyday life no one can leave the language because besides being a means of thinking, language is also used as a communication tool. A person's communication skills in language include 4 aspects, namely aspects of listening, speaking, reading and writing. These four aspects are also the scope that exists in English subjects. By mastering these four skills, it will facilitate the achievement of learning objectives and achievement of indicators in any existing English learning material.

Based on the Education Unit Level Curriculum, English language subjects in elementary school aim so that students have the following abilities, introducing English as a language of international communication, as debriefing for students, developing communication competencies in oral form, having awareness of the nature and importance of English. With this, students can improve and face the competitiveness of the nation in the future. In the four aspects mentioned above, there is the aspect of writing or also called writing skills. In learning English writing skills are the most difficult skills, because in writing students must have other skills as a component of writing skills such as vocabulary, grammar, spelling, and so on. The use of teaching materials in schools is sometimes not in accordance with the scope of learning of students, so it requires creativity from a teacher in creating his own teaching materials that are in accordance with the environment of students.

Based on the results of field visits conducted by researchers, many class II students were still having trouble writing words in English because they were still unable to remember each letter of the word to be written but were only able to remember the pronunciation. In the learning process the teacher applies a 
variety of methods, such as the lecture method, discussion, question and answer and teaching material by reading the subject matter. But the method applied is not appropriate for the learning so that student learning outcomes are not in accordance with the KKM that has been determined. We can see from the UTS value of English in class II of Kampung Melayu 1 Elementary School in Tangerang Regency, both from class A and $B$ which numbered 76 students who took UTS there were some students whose grades were below the Minimum completeness Criteria (KKM), the lowest value was 20 and the highest score of 95 based on the data is 40 people or around $52.63 \%$ who get KKM and while 36 students or $47.37 \%$ have not reached the $\mathrm{KKM}$, which is 65 .

To overcome this problem a learning method is needed that can improve writing skills. One method that can increase motivation and attract students' attention is the What's Missing method, where this method has the use of memorizing the vocabulary that has just been learned or mentioned, so that besides being able to memorize children, they can also know the letters written from each word without any difficulties, and writing wrong words in English.

\section{Writing Skills}

Writing skills According to Yeti Mulyati (2014), "Writing skills are skills acquired after studying them seriously and practicing a lot in order to improve writing skills" (p. 51). According to Byrne (1979), "Writing skills are the ability to put thoughts into written language through sentences that are arranged in full, complete, and clear so that the ideas can be communicated to the reader successfully" (Kundharu Suddhono and Slamet, 2014, p. 163). And according to Acep Hermawan (2014), "Writing skills are the ability to describe the contents of the mind, starting from simple aspects such as writing words to complex aspects of writing" (p. 151).

So that it can be concluded writing skills is a skill acquired after learning from practicing seriously, using written patterns of language to express an idea or message to the reader, starting from writing simple words to difficult ones which are making essays .

In learning to write all this time, generally the teacher only explained things related to theory. While writing training is less attention. With this, the teacher should use the reference, which must be taught is "writing" not "about writing". Students are invited to use their hands, paper and stationery to express their thoughts.

In carrying out learning, the teacher can use guided techniques. Suherli Kusmana (2010) explains the steps for learning to write with the technique are as follows:

1. Stage of speaking-writing.

2. Stage of writing.

3. Discussion.

4. Writing.

5. Strengthening process (p. 125).

\section{What's Missing Method}

In this study, to improve students 'writing skills given the learning method as an independent variable in the study is the learning method What's Missing. The definition of What's Missing method according to three theories, namely, According to Colin Granger (1993), "The meaning of What's Missing is a game where there are several groups divided, for example team A and team B then we need a number of different images (such as pencils), paper, cups, etc.) Place all the objects on the table, ask team A to go forward and see what is on the table within 1 minute, then throw 3 or a few objects at the table and add a new object. After that, ask for team A to see it and say what's missing, for Team 
B to say what's new. If the results of the observations are correct, then get point 2 , while for the grammar that gets the wrong points 1 . Repeat this activity with team $\mathrm{B}$, the group that gets the most points then is declared the winner "(p. 32). According to Gordon Lewis with Gunther Bedson (1999), "Explaining What's Missing is sitting in a circle with children. Ask them to give them something, such as a pencil. Add your own key or item. There must be between seven and ten objects at all. Place it in the middle of the tray or container. Hold each item and ask "what is this?" Practice saying words, first each child individually and then in the choir, until the children have good knowledge of all things. Cover objects with cloth. Ask one child to stand up and turn around. Remove one object from under the cloth, show the other children, and put it in the bag. The child who stands up turns again. Remove the cloth and ask what child is missing? He answered by asking, for example, is this a watch? Other children say yes, that or not, no. Every child gets his turn to try to guess what is missing"(p.125). According to Latifa Mutiara (2013), "What's Missing is a method where the teacher attaches a picture on the board, then asks students in the class to look at the pictures and try to remember them. The teacher asks them to close their eyes, then the teacher takes a few pictures on the board. After that the teacher asks the students to open their eyes again and mentions the missing image by asking one of the students, "What's Missing?" And the teacher asks the next question to the other students, "is he or right?" Students who can answer correctly will get points (p. 125).

So that it can be concluded What's Missing learning method is a method where the child must recall some images that have been removed by the teacher in the form of vocabulary. In this method the child is tested for memory to increase the vocabulary obtained in order to be trained in his writing skills, the child is not only trained in remembering but also trained in writing. Because usually children are easier to remember than having to rewrite words that are received especially in English.

\section{RESEARCH METHOD}

This research was conducted with quasi-experimental methods (quasi experiment). This research was conducted at Kampung Melayu 1 Elementary School in Tangerang Regency 2017/2018 Academic Year. The study sample consisted of two classes, namely class IIA and IIB, each class consisting of 38 students. The sampling technique uses purposive sampling techniques (Sugiyono, 2016). Because the sampling technique with certain considerations. The class chosen as the research sample is class IIA as the experimental class and class IIB as the control class.

The data in this study are quantitative data. Quantitative data in the form of writing skills test results on material names of animals. Consisting of 10 questions of writing skills, to see the effect of giving treatment to the experimental class and the control class, both experimental and control classes were given pretest and posttest. For pretest and posttest, different test devices are used. The results of the research data obtained are then analyzed by descriptive and inferential statistics. Testing of differences in the average posttest results using the test statistical technique.

\section{RESULTS AND DISCUSSION}

The questions that have been made by the researcher consist of 10 questions that have been tested by expert experts, namely the lecturers of English Language Subjects from the English 
learning syllabus as can be seen in table 1

Table 1. Instrument of Writing Skill in Elementary school

\begin{tabular}{|l|}
\hline Variable : Writing skill \\
\hline $\begin{array}{l}\text { Basic competence : } \\
\text { Copying English vocabulary is very } \\
\text { simple in its proper and correct spelling }\end{array}$ \\
\hline $\begin{array}{l}\text { Indicator: } \\
\text { Copy and match words with appropriate } \\
\text { images }\end{array}$ \\
\hline
\end{tabular}

Based on Table 1, after the questions were tested by expert experts, all questions were feasible and had met the validation requirements. Then the test is used in the study. The results of the research data were then tested for normality and homogeneity tests, and the results were declared to meet normal and homogeneous requirements. So that the hypothesis can be tested against writing skills tests. Descriptively the pretest and posttest data for writing skills can be seen in Table 2.

Table 2. Summary of Pretest and Postest Score

\begin{tabular}{|l|c|c|}
\hline \multicolumn{1}{|c|}{ Class } & $\begin{array}{c}\text { Average of } \\
\text { pretest } \\
\text { score }\end{array}$ & $\begin{array}{c}\text { Average of } \\
\text { posttest } \\
\text { score }\end{array}$ \\
\hline Experiment & 55,2 & 76,2 \\
\hline control & 56,7 & 58,6 \\
\hline
\end{tabular}

In Table 2, it shows that the experimental class is higher than the control class, both classes belong to the medium category. Based on the results of the t-test analysis on the variable writing skills, between the experimental group and the control group are shown in Table 3.

Table 3. T-Test of Writing skill test Experimen and control class

\begin{tabular}{|c|c|c|}
\hline \multirow{2}{*}{ Uji-T } & $\mathbf{T}_{\text {hitung }}$ & $\begin{array}{c}\mathbf{T}_{\text {tabel }}\left(\mathbf{1}-\frac{\alpha}{2}\right) \mathbf{t}\left(\mathbf{n}_{\mathbf{1}}\right. \\
\left.+\mathbf{n}_{2}-\mathbf{2}\right)\end{array}$ \\
\cline { 2 - 3 } & 6,06 & 2,00 \\
\hline
\end{tabular}

Based on Table 3, it shows that tcount $=6.06$ is greater than $\mathrm{t}$ table $=$ 2.00 for $\mathrm{db}=74$ at $\alpha=5 \%$, because Thitung $>\mathrm{T}$ table then $\mathrm{HO}$ is rejected and alternative hypothesis (H1) is accepted. It can be interpreted that there is an influence on writing skills that are given What's Missing learning methods with those given conventional learning methods. The results of this test at the same time prove that there is an influence on the results of student writing skills is not a coincidence, but because of differences in treatment given to the experimental class and the control class. So that it can be concluded that giving treatment using What's Missing learning method can have a positive effect on students' writing skills, and the efficiency of the English teaching and learning process can be improved using the What's Missing learning method.

After learning the material the names of animals with the What's Missing learning method in the experimental class can affect student learning outcomes, because the learning method has advantages such as students not silent at all in class, encouraging students to increase their initiative or participation during learning, students become active in the learning process, and cultivate habits in students to share, provide input and openness to responses / criticism.

Such learning process, resulting in learning activities in the experimental class and control class affect the 
students' writing skills. In the experimental class given What's Missing learning method gives a better influence on students' writing skills compared to learning through conventional learning methods. Where students are able to increase their confidence if they are told to go ahead and write in front of the class. Thus, students in the class during the learning process are not silent at all because each student is given the opportunity to progress and write in front of the class to deliver the material taught. Thus this learning method can increase learning motivation in students, and during the learning process the writing skills in students can improve better.

Although the What's Missing learning method is successful in improving students' writing skills, there are still some obstacles that were experienced when the research took place, especially in the experimental class which previously in class learning students still lacked confidence. In What's Missing learning method students must be more involved in learning, and each student is given the opportunity to write in front of the class. Thus, researchers need to prepare a considerable amount of time and also easy-to-understand and interesting teaching materials for students so that they can inspire learning and be active in learning, one of which is giving rewards to students and appreciating every work that students have done.

\section{CONCLUSSION}

The results of the study can be concluded that the calculation of the hypothesis test with the T-test obtained the calculation that tcount $=6.06$ while $\mathrm{t}$ table $=2.00$ thus $\mathrm{t}$ count $>\mathrm{t}$ table $(\alpha=$ $0.05)$, then $\mathrm{HO}$ is rejected and $\mathrm{H} 1$ is accepted. Based on the learning outcomes obtained, it can be concluded that there is an effect of writing skills on students who learn to use the What's Missing learning model compared to conventional learning methods.

Based on the results of the research that has been done, it shows that by using What's Missing learning method there is an influence on writing skills in class II students. When the application of learning in the classroom by using this method can make students more active and motivated in learning, because the learning done involves more students in it so that students are more easily aware of the subject matter given, and no students are silent at all on during the learning process.

It can be said that classroom learning runs smoothly and gets good results. So What's Missing learning method can be applied in the classroom by the teacher to provide variation in the learning process so that learning does not feel bored quickly.

\section{REFERENCES}

G, Colin. (1993). Play games with English 1: Teacher's resource book. Oxford: Macmillan Publishers Limited. http://en.bookfi.net/book/1124180 diakses 14-06-2017

Hermawan, Acep. (2014). Metodologi Pembelajaran Bahasa Arab. Bandung: PT. Remaja Rosdakarya. Kusmana, Suherli. (2010). Guru Bahasa Indonesia Profesional. Jakarta: Sketsa Aksara Lalitya.

Lewis, Grodon with Gunther Bedson. (1999). Games for children: Resource books for teachers. Oxford: Oxford University press. http://en.bookfi.net/book/1290102 diakses 14-06-2017

Mulyati, Yeti. (2014). Keterampilan Berbahasa Indonesia SD. Tangerang Selatan: Universitas Terbuka.

Mutiara, Latifa. (2013). 68 Game Kreatif Pembuka dan Penutup Kelas. 
Yogyakarta: $\quad$ Langensari

Publishing.

Saddhono, Kundharu. (2014).

Pembelajaran Keterampilan

Berbahasa Indonesia Teori dan Aplikasi. Yogyakarta: Graha Ilmu.

Sugiyono. (2016). Metode Penelitian

Kuantitatif, Kualitatif, dan $R \& D$.

Bandung: CV. Alfabeta. 